\title{
Marlene Nourbese Philip's "Bad Words"
}

\author{
Leslie Sanders
}

\section{"Des gros mots" de Marlene Nourbese Philip}

Une écrivaine $d u$ "nouveau monde," Nourbese Philip s'appellait Nourbese, un mot Bénin voulant dire "enfant merveilleux," un nom choisi pour invoquer l'héritage, le passage et le voyage. Il y a bien des points d'entrée en analyse de son oeuvre riche et dense, et "Bad Words" peut sembler un texte peu propice pour celles qui connaissent son oeuvre poétique antérieur. Cependant, le côtéludique, iconoclaste de ce texte tout comme la profondeur de sa pensée marquent un point tournant dans la quête de Nourbese Philip pour un paysage et une langue, soulignant certains points clés de son oeuvre tout en indiquant des voies nouvelles. L'héroïne de "Bad Words," Miranda, âgée de 12 ans, envie un garçon $q$ qu' elle vient de rencontrer son langage grossier, surtout ses sacrés. Elle les répète en privé, avançant de "fuck" ("foutre") à "cunt" ("con") à "Mothercunt" ("conasse"), deux mots contradictoires, l'un tout la sécurité et le confort, l'autre le dur et le ménaçant. La compétence de Miranda se dévéloppe lorsqu'elle rencontre Pomona, une grande femme dont les jurons se mésurent à la béauté. Miranda lance ses jurons un dimanche après l'église chez des voisins et est sévèrement punie. Un dilemme se pose alors: comment rendre ses mots efficaces tout en les gardant interdits? Ici Nourbese Philip soulève la question de la génération. Les mots des parents de Miranda expriment le désir des Africains du Nouveau Monde de quitter l'esclavage pour devenir citoyens, démocrates. La langue de Miranda présente un défi autrement dangéreux au statu quo, celui d'une libération radicale. Le dilemme est situé symboliquement dans le corps de la femme, dans les codes non verbalisés qui règlent la sexualité des femmes, reléguée aux silence, les femmes écartées ainsi du discours de l'histoire. Miranda atteint les structures de classes, de l'impérialisme, et du "gender" avec le sacréen anglais "démotique." La langue parlée par les parents de Miranda avec l'héritage de 500 ans d'histoire dans le Nouveau Monde est une langue que ne marque pas la sexuation du discours, une langue alors $d u$ 
côté du masculin. Articuler le féminin dans cette histoire et ce language est le projet de Philip, un projet potentiellement dangéreux. Mais le danger choisi est un risque engagé qui peut produire du neuf. Philip avait déjà formulé la résistance aux pouvoirs impérialistes et sexistes dans une image de l'espace sexué. Le rapport des fermmes à l'espace est déterminé par une relation de l'intérieur et de l'extérieur, c'est à dire, une relation de l'espace entre les jambes à l'espace publique. Les femmes noires sont venues au Nouveau Mondes avec leurs corps comme leur seul bien. La fente entre les jambes est devenue le site de leur oppression, la partie asservie à la réproduction de la machinerie de la plantation, lieu de leur servitude. La "jammette," femme libre, refuse les normes, et marque les limites des discours, un espace entre, sorte de zone libre, qu'elle s'est créee, entre deux modes de contraintes. Dans "Elle essaie sa langue," Nourbese Philip a refusé sa propre place dans le langage et le discours littéraires en écrivant un genre de "créole" qu'elle a forgé ("demotic") et en produisant des poèmes qui s'étendent sur toute la page, déplaçant les distinctions entre le texte et le marge, entre le haut et le bas de la page. Elle raconte ici une double diaspora, celle de l'Africaine au Nouveau Monde, celle de la Caribbéanne au nord. Pour l'Africaine du Nouveau Monde, il faut exposer les abus du pouvoir sur sa sexualitéet se faire un lieu sûr pour ellemême dans un "dé-place(ment)."

A "New World" writer, Nourbese Philip calls herself; Nourbese is Benin and means "marvellous child," a name she chose as an invocation of ancestry, passage and journey. Born in Tobago and raised in Trinidad, Philip now lives in Toronto. Her published works include: three volumes of poetry, Thorns (1980), Salmon Courage (1983) and She Tries Her Tongue, Her Silence Softly Breaks (1989); the latter collection, in manuscript, won the Casa delas Americas prize for 1988. As well, she has written a novel for young people, Harriet's Daughter (1988), a mixed genre fiction, Looking For Livingstone (1991), numerous essays and several short stories.

There are many ways of entering into Philip's increasingly rich and complex artistic project, many ways of contemplating her central concerns. Her recent short story called "Bad Words" may, to those who know her earlier work, seem an odd place to start, but I present it as a point of entry because its irreverence, playfulness and philosophical depth seem to mark a turning point in the artist's quest for imaginative landscape and language, consolidating matters that have continually 
engaged her, while also pointing in new directions.

The heroine of "Bad Words," 12-year-old Miranda, has just met a boy, and immediately "envied him! this new found friend of hers. The way he cursed" (30). Miranda practices this new form of discourse, in private naturally, progressing from "fuck" to "cunt" to "Mother and cunt." In their opposition the two words - one resonant with safety and comfort, the other harsh, defiant and threatening - were locked together irrevocably"(30). Miranda's mastery develops when she acquires a better role model, a woman whose splendid appearance is matched by her talent for expletives: "Pomona Adams [was] ... a large and beautiful brownskinned woman ... close to six feet with full shapely breasts ... high heels ... and ... the largest behind Miranda had ever seen". [She walked with] "a prideful determination that matched her size ... .mashing the ground as if she owned it" (32).

In contrast to Pomona Adams, and to the language "of badness" which Miranda sought to develop, Miranda's parents spoke "words which they had stoked and fired into life and now would not let die, words which under the lash and caress of their tongues now transformed themselves - slavery into freedom, nigger into human. Miranda ... knew that like her they were entering forbidden spaces, naming now what they had only dared to dream of before. In secret" (33).

When Miranda finally unleashes the full range of her well-rehearsed vocabulary, on a Sunday no less, while visiting neighbours with her family after church, her punishment is as she expected. The resultant weals on her arms and legs become for her "painful proof of her allegiance with Pomona Adams. And the truth ... Having uttered them Miranda now felt that she had made the words good, especially the mother's curse, but now she wanted very much to keep the power of their badness. And how was she to do that - make them good yet keep them bad? On that thought Miranda fell asleep" (33).

Important to Philip's concerns in "Bad Words" is the matter of generation: whereas Miranda's parents' words express the desire of the New World African moving out of slavery and into liberal democratic citizenship, her language presents a different danger and a still more radical form of emancipation and license.

In some respects, in "Bad Words" Philip is simply defying the strictures imposed on the "good girl," but those behaviourial codes conceal the always unnamed: female sexuality, rendered enigmatic by silence; women, rendered invisible because unmentioned in the discourses that 
constitute history. Pomona challenges the respectability imposed on Miranda by virtue of class difference, but she also signals the presence of the demotic, the source for language that will shake loose from its moorings the "standard" and proper English in which the discourses of power are written (and whose deconstruction is one of Philip's preoccupations). Moreover, in Miranda's understanding of the "badness" of her words, the "Great Mothers" of various mythologies are contained.

In terms of issues of gender and generation, Philip's interest is not merely self-understanding, nor a generic experience of womanhood. Crucial to her purpose is that the language of Miranda's parents, signifying as it does, five hundred years of New World and African history, is apparently without reference to gender - more accurately it is generically, and except for emancipation itself literally, in the masculine. Locating and articulating women's presence in that world and that history is Philip's concern, and to do so is, she suggests, dangerous. Danger is both negative and a source of creativity, however. Chosen, danger becomes risk, risk-taking, without which enlightenment is impossible.

All these matters also preoccupied Philip in her talk at the second conference of Caribbean Women Writers, held in Port of Spain in March 1990. Called "Dis Place - The Space Between," the talk she gave evokes images of Miranda grown. Early in the talk, Philip argued that space is gendered because its quality is, for women, determined by the safety of their inner space in the outer space surrounding them. She continued:

Whether we conceive of the space between the legs as one space, the cunt; two spaces, the cunt and womb; or one continuous space extending from cunt to womb, control of and over this space or spaces is a significant marker of the outer space... The black woman came to the New World with only the body and that most precious of resources - the space between her legs ... the space between the black woman's legs became the place - site of oppression - necessary and vital to the cultivation and continuation of the outer spaces in a designated form - the plantation machine ... (3-4).

Philip locates her introductory theorizing in the historical figure of the Jamette: "from diametre, the diameter, that divided the world between the space and place of respectability and that of the underworld, the lower classes. A jamette was always female and belonged to that world and class. Jamette: a loose woman, a woman of loose morals, whose habi- 
tat was the street; a woman who possessed both the space between her legs and the space around her; she knew her place, on the streets of Port of Spain"(6).

The jamette's place, which Philip calls itself a boundary, appears margin both to the respectable community, which denies female sexuality, and more typical street life, which exploits it. The Jamette's place becomes a space because she possesses it; the world mapped from her position recedes on both sides into realms of confinement, censorship, and oppression. Two years earlier, in her talk at the First International Conference of Caribbean Women Writers, Philip had suggested the power of 'dis place'. "Managing the Unmanageable" meditates on the paradox of naming the Other (women, Africans, Asians, and aboriginals) simultaneously inferior and threatening. Based on the journals Philip kept while composing She Tries Her Tongue ... , the essay explores her attempt to understand the implications of working in a language which "traditionally had been yet another tool of oppression, a language that has at best omitted the reality and experience of the managed - the African in the New World - and at worst discoursed on her nonbeing" (296). A result of her understanding was a "refusal to 'know my place' ... many of the poems in She Tries Her Tongue ... have become unreadable in the traditional sense" (297). Sprawled over the page and into margins, the poems are repeatedly interrupted. Body, too, "erupt[ed] into the text - tongue, lips, brain, penis - the body insisted on being present throughout She Tries ... (298)".

English

is my mother tongue

A mother tongue is not not a foreign lan lan lang language

1/anguish anguish

-a foreign anguish

English is

my father tongue.

A father tongue is a foreign language, therefore English is 
a foreign language

not a mother tongue.

What is my mother

tongue

my mammy tongue

my mummy tongue

my momsy tongue

my modder tongue

my ma tongue?

I have no mother

tongue

no mother to tongue

no tongue to mother

to mother

tongue

me

I must therefore be tongue

dumb

dumb-tongued

dub-tongued

damn dumb tongue

Surrounding this lament, literally in the margins, on the left, in capital letters, Mother licks her child clean and blows life into her mouth. In the right, bracketing the meditation on mother tongue, stand two edicts which command that slaves be deprived of native language, and if they resist, of their tongues. Two forms of discourse concerning the biology of the brain also intrude upon the poem's main thrust: the first recounts how the speech centres of the brain acquired their names, the second consists of multiple choice questions, ranging from poignant to humorous, probing the nature of tongues. The lament continues:

but I have

a dumb tongue

tongue dumb

father tongue

and english is 
my mother tongue

is

my father tongue

is a foreign lan lan lang

language

1/anguish

anguish

a foreign anguish

is english -

another tongue

my mother

mammy

mummy

moder

mater

macer

moder

tongue

mothertongue

tongue mother

tongue me

mothertongue me

mother me

touch me

with the tongue of your

lan lan lang

language

1/anguish

anguish

english

is a foreign anguish

(Discourse on the Logic of Language)

Other poems in the volume employ various strategies for appropriating or imprinting the black experience on the European linguistic/cultural imposition and inheritance. "Recreating our own histories and myths," the poet calls these activities in the introductory essay. For example, the first series of poems in the volume, "Over Every Land and Sea" cites fragments of Ovid's account of Ceres' search for 
Proserpine, each poem rendering mother-loss, and blood: mark of violation, of birth and menses marks the trail, but the child is not found. Present in this series is a double diaspora: of the African to the New World and the Caribbean migration north to Canada specifically, but also the United States, and England.

Most of the poems meditate on the nature of language: "Meditations on the Declension of Beauty by the Girl with the Flying Cheek-bones," for example:

If not If not If

Not

If not in yours

In whose

In whose language

Am I

If not in yours ....

If not in yours

In whose

In whose language

Am I

If not in yours

Beautiful

Building on texts taken from Noam Chomsky, the poem "Universal Grammar" juxtaposes various definitions, grammatical exercises and argument for the biological root of how we learn language, with the musing:

when the smallest cell remembers -

how do you

how can you

when the smallest cell

remembers

lose a language

She Tries Her Tongue ... is about English, lamenting it, deconstructing it, wrenching from it the eloquence that it denies the speaker and her world.

The relation is profound between the discourse in which "slavery/freedom" and "nigger/human" mark the limits of desire and the end of struggle, and the discourse of "bad words" which dare to 
name "the space between the black woman's legs," "the place," cunt and womb, as the site of slavery, and so the proper basis of any historical narrative of the Caribbean. For the New World African woman, virtually nothing can be accomplished until the abuse of her sexuality can be made evident and her safety, defined as the reclamation of 'dis space', secured.

\section{Works Cited}

Philip, Marlene Nourbese. She Tries Her Tongue, Her Silence Softly Breaks. Charlottetown: Ragweed Press, 1989.

. "Bad Words". Border/Lines: cultures contexts canadas (Spring 1990): 30-33.

. "Dis Place-The Space Between". Mss. Courtesy of author. . "Managing the Unmanageable." Caribbean Women Writers:

Essays from the First International Conference. ed. Selwyn Cudjoe.

Wellesley MA: Calaloux Publications, 1990: 295-300. 